\title{
HUBUNGAN SANITASI RUMAH DENGAN KEJADIAN TUBERKULOSIS PARU DI WILAYAH KERJA PUSKESMAS II DENPASAR BARAT
}

\author{
Ni Komang Ayu Tria Meriyanti dan I Wayan Sudiadnyana
}

\begin{abstract}
Tuberculosis is an infectious disease of human caused by a species of mycrobacterium mainly infecting the lungs. Mycrobacterium germs are easy to breed in places with poor environmental conditions poor home conditions influenced by sanitation. The porpused of this study to find out the relation of house sanitation with the incidence of tuberculosis in the working area of Puskesmas II West Denpasar. This research is an observation research with case control. Variables in house sanitation namely the level of lighting, humidity, ventilation, temperature and density. The data obtained were tested by chi square test obtained result correlation lighting level ( $p$ value $=0,000)$, humidity $(p$ value $=0,000)$, ventilation ( $p$ value $=0,000)$ temperature $(p$ value $=0,066)$ and density $(p$ value $=$ 0,472) with incidence of tuberculosis in working area of Puskesmas II West Denpasar in 2018. It is recommended that homeowners open windows regularly to prevent TB transmission
\end{abstract}

Keywords: House sanitation, pulmonary tuberculosis

\section{Pendahuluan}

Tuberkulosis (TB) paru adalah penyakit menular langsung yang disebabkan oleh kuman Tuberkulosis yaitu Mycobacterium Tuberculosis. Sebagian besar kuman Tuberkulosis menyerang paru, tetapi dapat juga mengenai organ tubuh lainnya. Kuman ini berbentuk batang mempunyai sifat khusus yaitu tahan terhadap asam pada pewarnaan oleh karena itu disebut pula sebagai basil tahan asam (BTA) ${ }^{1}$.

Penyakit TB paru merupakan masalah utama kesehatan masyarakat di Indonesia. Jumlah penderita TB paru di Indonesia merupakan ke-3 terbanyak di dunia setelah India dan Cina dengan jumlah penderita sekitar $10 \%$ dari total jumlah penderita TB paru dunia. Diperkirakan pada tahun 2004, setiap tahun ada 539.000 kasus baru dan kematian 101.000 orang. Insidensi kasus TB paru BTA positif sekitar 110 per 100.0000 penduduk ${ }^{1}$. Kasus Tb Paru di Kota Denpasar cukup tinggi dan wilayah Puskesmas II Denpasar Barat sebagai penyumbang kasus TB terbanyak tahun 2017 sebanyak 67 kasus.

Berdasarkan latar belakang diatas penulis tertarik untuk melakukan penelitian tentang "Hubungan keadaan sanitasi rumah dengan kejadian TB paru di wilayah kerja Puskesmas II Denpasar Barat”.

\section{Metode}

Penelitian ini merupakan penelitian observasional dengan metode case control, yaitu penelitian epidemiologi analitik yang bersifat observasi dimana dilakukan perbandingan antara sekelompok orang yang menderita penyakit (kasus) dengan sekelompok lainnya yang tidak menderita penyakit

1 Mahasiswa Jurusan Kesehatan Lingkungan Poltekkes Denpasar

2 Dosen Jurusan Kesehatan Lingkungan Poltekkes Denpasar 
tersebut (kontrol), kemudian dicari faktor-faktor penyebab timbulnya suatu penyakit ${ }^{2}$.

Penelitian ini dilakukan di wilayah kerja Puskesmas II Denpasar Barat. Jumlah kasus Tb yang berobat ke Puskesmas pada periode bulan Januari sampai Mei 2018 sebanyak 22 kasus. Kontrol juga diambil 22 kasus yaitu pasien yang berobat ke puskesmas bukan penderita TB. Variabel sanitasi rumah yang dikumpulkan adalah : pencahayaan, kelembaban, ventilasi, suhu, kepadatan hunian, kondisi sanitasi total.

\section{Hasil Penelitian}

Berdasarkan hasil pengumpulan data kedaaan sanitasi rumah dan hubungannya dengan kejadian TB paru di wilayah kerja Puskesmas II Denpasar Barat tahun 2018, dapat dilihat pada tabel 1 di bawah ini.

Tabel 1

Tabulasi Silang Keadaan Sanitasi Rumah dengan Kejadian TB

\begin{tabular}{|c|c|c|c|c|}
\hline Variabel & Indikator & Kasus & Kontrol & $\mathrm{p}$ value \\
\hline \multirow{2}{*}{ Pencahayaan } & TMS & 21 & 7 & \multirow{2}{*}{0,000} \\
\hline & MS & 1 & 15 & \\
\hline \multirow{2}{*}{ Kelembaban } & TMS & 20 & 4 & \multirow{2}{*}{0,000} \\
\hline & MS & 2 & 18 & \\
\hline \multirow{2}{*}{ Ventilasi } & TMS & 18 & 8 & \multirow{2}{*}{0,002} \\
\hline & MS & 4 & 14 & \\
\hline \multirow{2}{*}{ Suhu } & TMS & 16 & 10 & \multirow{2}{*}{0,066} \\
\hline & MS & 6 & 12 & \\
\hline \multirow{2}{*}{$\begin{array}{l}\text { Kepadatan } \\
\text { hunian }\end{array}$} & TMS & 6 & 4 & \multirow[t]{2}{*}{0,472} \\
\hline & MS & 16 & 18 & \\
\hline \multirow{2}{*}{$\begin{array}{l}\text { Sanitasi } \\
\text { rumah }\end{array}$} & TMS & 20 & 5 & \multirow{2}{*}{0,000} \\
\hline & MS & 2 & 17 & \\
\hline
\end{tabular}

Keterangan :

TMS : Tidak Memenuhi Syarat

MS : Memenuhi Syarat

Dari tabel 1 kelihatan bahwa keadaan sanitasi rumah secara umum berhubungan dengan kejadian kasus TB paru dengan nilai $\rho<0,05$, kecuali suhu dan kepadatan hunian yang tidak berhubungan dengan nilai $\rho \geq 0,05$.

\section{Pembahasan}

1. Hubungan tingkat pencahayaan, kelembaban dan ventilasi rumah dengan kejadian TB Paru

Berdasarkan data yang diperoleh di wilayah Puskesmas II Denpasar Barat didapat hasil masih banyak rumah yang tidak memenuhi syarat kesehatan ditinjau dari segi pencahayaan, kelembaban dan 
ventilasi. Kondisi ini merupakan faktor risiko dari penularan penyakit TB. Hasil pengujian statistik menunjukkan bahwa ada hubungan kelembaban, pencahayaan dan ventilasi rumah dengan kejadian TB paru.

Pada dasarnya ketiga faktor
diatas saling terkait, faktor
pencahayaan dan ventilasi akan
memberi pengaruh terhadap kelembaban ruangan. Ruangan yang kurang pencahayaan dan ventilasi akan cendrung menjadi lembab. Kondisi rumah seperti ini sangat mendukung penyebaran TB Paru. Mycrobacterium tuberculosis sebagai penyebab penyakit TB dapat bertahan hidup bertahun-tahun pada tempat yang sejuk, lembab, tanpa sinar matahari dan mati apabila terkena sinar matahari. Ventilasi dan cahaya matahari dapat membunuh bakteribakteri patogen dalam rumah termasuk bakteri tuberkulosis. Fungsi ventilasi dalam rumah selain menjaga aliran udara juga membebaskan udara ruangan dari bakteri-bakteri terutama bakteri pathogen. Oleh karena itu penting adanya jalan masuk udara dan cahaya ke dalam rumah melalui jendela maupun genteng kaca.

Cahaya yang masuk juga harus merupakan sinar matahari pagi yang mengandung sinar ultraviolet yang dapat mematikan kuman, dan memungkinkan lama menyinari lantai bukan hanya dinding ${ }^{3}$. Risiko terjadinya penularan TB pada rumah yang tidak dimasuki sinar matahari adalah 3,5 kali lebih besar dibanding rumah yang dimasuki sinar matahari 4.

2. Hubungan suhu dan kepadatan hunian rumah dengan kejadian TB Paru.
Berdasarkan data yang diperoleh di wilayah Puskesmas II Denpasar Barat didapat hasil masih banyak rumah yang tidak memenuhi syarat kesehatan ditinjau dari segi suhu namun dari segi kepadatan hunian lebih banyak memenuhi persyaratan. Penelitian yang sejenis dilakukan oleh Sadono tentang gambaran sanitasi lingkungan pemukiman mendapatkan hasil bahwa kepadatan hunian di Perumahan Pakis Tirtasari Surabaya hampir seluruhnya memenuhi persyaratan kesehatan (sadono). Berdasarkan data suhu dan kepadatan hunian setelah dilakukan pengujian statistik ternyata tidak ada hubungan antara suhu dan kepadatan hunian dengan kejadian TB paru.

Suhu udara di wilayah Kota Denpasar dan sekitarnya cenderung panas karena berada pada wilayah dekat pantai. Suhu ruangan dalam rumah berpengaruh terhadap kenyamanan penghuni. Persyaratan suhu dalam rumah menurut Permenkes RI No.1077/Menkes/ Per/V/2011 berkisar antara $18^{0}$ $30^{\circ} \mathrm{C}$. Sedangkan suhu optimal untuk pertumbuhan bakteri sangat bervariasi, bentuk psikhrofilik tumbuh baik pada suhu rendah antara $15^{\circ}-20^{\circ} \mathrm{C}$. Persyaratan untuk kepadatan hunian untuk seluruh perumahan biasa dinyatakan dalam $\mathrm{m}^{2}$ per orang. Luas minimum per orang sangat relatif, tergantung dari kualitas bangunan dan fasilitas yang tersedia. Untuk perumahan sederhana minimum $9 \mathrm{~m}^{2}$ per orang. Untuk kamar tidur di perlukan minimum 3 $\mathrm{m}^{2}$ per orang. Kamar tidur sebaiknya tidak dihuni $\geq 2$ orang kecuali untuk suami istri dan anak di bawah 2 tahun. Jarak antara tempat tidur satu dengan lainnya adalah $90 \mathrm{~cm}$. Apabila ada anggota keluarga yang menderita

1 Mahasiswa Jurusan Kesehatan Lingkungan Poltekkes Denpasar

2 Dosen Jurusan Kesehatan Lingkungan Poltekkes Denpasar 
penyakit TB paru sebaiknya tidak tidur bersama dengan anggota keluarga lainnya ${ }^{5}$.

3. Hubungan keadaan sanitasi rumah dengan kejadian TB Paru

Hasil rekaputulasi data keadaan sanitasi rumah total berdasarkan variabel pencahayaan, kelembaban, ventilasi, suhu dan kepadatan hunian didapatkan data dari 22 rumah kasus TB 20 rumah (91\%) tidak memenuhi persyaratan dan hanya 2 rumah $(9 \%)$ memenuhi persyaratan. Setelah dilakukan pengujian statistik dibandingkan dengan kelompok kontrol dapat disimpulkan ada hubungan keadaan sanitasi rumah dengan kejadian TB di wilayah Puskesmas II Denpasar Barat.

Sanitasi adalah upaya kesehatan dengan cara memelihara dan melindungi kebersihan lingkungan. Kebersihan lingkungan adalah faktor utama yang berpengaruh dalam penularan atau penyebaran suatu penyakit. Semakin baik sanitasi rumah maka semakin kecil penyebaran penyakit yang terjadi begitupula sebaliknya (Depkes RI, 2008). Kebersihan lingkungan di kawasan perumahan dapat diupayakan melalu gerakan gotong royong untuk meningkatkan solidaritas masyarakat menciptakan lingkungan perumahan yang layak huni ${ }^{6}$.

\section{Simpulan}

1. Ada hubungan antara tingkat pencahayaan, kelembaban dan ventilasi rumah dengan kejadian TB di wilayah kerja Puskesmas II Denpasar Barat.

2. Tidak ada hubungan antara kepadatan hunian dan suhu rumah dengan kejadian TB Paru di wilayah kerja Puskesmas II Denpasar Barat

3. Ada hubungan antara keadaan sanitasi rumah dengan kejadian TB Paru di wilayah kerja Puskesmas II Denpasar Barat

\section{Saran}

Kepada pemilik rumah disarankan agar rutin membuka jendela dan membiarkan cahaya matahari masuk rumah untuk mencegah dan meminimalisasi penularan penyakit TB. Masyarakat secara bersama perlu melakukan kegiatan gotong royong untuk mewujudkan lingkungan perumahan yang layak huni dan terbebas dari berbagai penularan penyakit berbasis lingkungan.

\section{Daftar Pustaka}

1. Depkes-RI. Pedoman Penanggulangan Tuberculosis. (2008).

2. Azwar, A. Pengantar Epidemiologi. (Binapura Aksara, 2017).

3. Notoatmodjo, S. Prinsip Dasar Ilmu Kesehatan Masyarakat. (Rineka Cipta, 2007).

4. Heryanto-dkk. Riwayat Pengobatan Penderita TB Paru Meninggal di Kabupaten Bandung. J. Ekol. Kesehat. 3, 1-6 (2004).

5. Kemenkes-RI. Persyaratan Kesehatan Perumahan. (1999).

6. Yulianti, E. T. PENGELOLAAN SANITASI DI PEMUKIMAN KUMUH (Studi di Gunung Pala Kelurahan Keteguhan Kecamatan Teluk Betung Timur Kota Bandar Lampung). (2017). 